Akhapov Ye.A., Dairova A.S.

Apology speeches from linguistic view

Ахапов Е.А., Ааирова А.С.

Кешірім сұрау категориясына мингвистикалық тұрғыдан жаңа көзқарас

Ахапов Е.А., Ааирова А.С.

Категория извинения с точки зрения кингвистики
Today's linguistic studies, both basic and applied, show a marked tendency to become more and more data-oriented. So, that is why we will try to use our previous theoretical knowledge in practice and look on the "apology" from linguistic point of view using different types of resources. In our survey study we used some role play cards to have an interview with Japanese native speakers. We also had an interview with Russian native speakers in order to have some experience.

Key words: apology strategies, linguistic, role play cards, interview, research methods.

Қазіргі таңда лингвистиканы ғылыми және қолданбалы тұрғыдан да алып қарасақ, математикалық есептеулерге көбірек жүгінетіні байқалады. Сондықтан, осы мақалада зерттеудің жаңа әдіс-тәсілдері мен теоретикалық білімімізді тәжірибе жүзінде қолдана отырып, «кешірім сұрауды» мингвистикалық, көзқараспен қарастырдық. Статистикалық мәліметтерді алу үшін рөлдік карточкалар көмегімен интервью тәсілі пайдаяаны^ды. Сонымен қатар, орыс тілінде сөйлеуші респонденттермен алдын ала интервью жүргізілді.

Түйін сөздер: кешірім сұрау стратегиясы, мингвистика, рөлдік ойындар карточкасы, интервью, зерттеу әдістері.

На сегодняшний день мингвистика, как прикладная, так и фундаментальная, все чаще прибегает к математическим расчетам. Поэтому в Аанной работе мы попытались использовать наши теоретические знания на практике и рассмотреть «извинение» с точки зрения мингвистики, используя новые методы исследования. Аля получения статистических Аанных был использован метод интервью с использованием ролевых карточек. К тому же было проведено предварительное интервью с носителями русского языка.

Кмючевые слова: стратегии извинения, мингвистика, ролевые карточки, интервью, методы исследования. 
UDC 811-521’36

Akhapov Ye.A., Dairova A.S.

Al-Farabi Kazakh National University, Kazakhstan, Almaty

E-mail: aizhana-93k@mail.ru

\section{APOLOGY SPEECHES FROM LINGUISTIC VIEW}

\section{Introduction}

The way apologies are classified depends very much on the way they are defined. Thus, the diversity in definitions of apologies also brings about diversity in classification. There are certain types of apologies that are common across different categorizations, while other types are unique. Several studies have argued that the expression of sympathy must be coupled with a statement of responsibility. There are some main apology strategies that we used in our survey study, so we will focused on them a lit bit.

Previous works

Bruce Fraser's apology strategies (1980)

Bruce Fraser suggested nine apology strategies:

Announcing that you are apologizing.

Stating one's obligation to apologize.

Offering to apologize.

Requesting the hearer to accept an apology.

Expressing regret for the offence.

Requesting forgiveness for the offence.

Acknowledging responsibility for the offending act.

Promising forbiddance from a similar offending act.

Offering redness.

Andrew Cohen, Elite Olshtain and Rosenstein's apology strategies (1981)

The categorization of A. Cohen and E. Olshtain looks like: IFID)

An expression of apology (Illocutionary Force Indicating Device

an expression of regret (e. g. I'm sorry)

an offer of apology (e.g. I apologize)

a request for forgiveness (e.g. excuse me, forgive me)

An offer of repair/redress (e.g. I'll pay for your damage)

An explanation of an account (e.g. I missed the bus)

Acknowledging responsibility for the offense (e.g. It's my fault)

A promise of forbearance (e.g. I'll never forget it again)

This categorization is a very important one and useful for the present studies because, unlike Bergman and Kasper's taxonomy, it takes into account situation when even though the hearer believes the speaker should apologize, the latter does not. We would even 
include another category in the second part, namely postponing an apology, as in this case there is no apology given at the moment of speaking, either. Olshtain and Blum-Kulka carried out a study on requests and apologies with native speakers of Hebrew and learners of Hebrew. They found that the learners of Hebrew approached native speaker norms when they had the same rules in their native languages and deviated from native speakers when they had language-specific rules. They also found that nonnatives' length of stay in the target language community affected their choice of the formulas. A very similar taxonomy was the basis of the CrossCultural Speech Act Realization Project, and it comprises seven strategies to perform apologies: using an illocutionary force indicating device, taking on responsibility, explanation or account of what happened, offer to repair the offending act, promise of forbearance. These strategies can be used, according to the authors, by themselves, or in any combination or sequence.

Olshtain and Cohen's taxonomy was also modified by Holmes, who believed that it was necessary to rearrange these strategies in order to make them clearer. Thus, she divided apologies into four main categories, each category having sub classifications. The first one is an explicit expression of apology and contains the subcategories offer apology, express regret, request forgiveness. The second main category is represented by an explanation or account, an excuse or justification. The largest group, an acknowledgment of responsibility, contains accept blame, express selfdeficiency, recognize as entitled to an apology, express lack of intent, offer repair/redress. Finally, the last category is a promise of forbearance". While most of these categories are present in other taxonomies, as well, one can note that most of the ones in the "acknowledgment of responsibility group are unique to Holmes.

A slightly different taxonomy was proposed by Trosborg, who distinguished five categories. She found that apologetic strategies can be divided according to whether the speaker considers that an action that requires an apology occurred or not. The first two categories come from the speaker's not accepting that an apology is necessary, and are explicit denial and implicit denial. The remaining three categories are the result of the speaker accepting the fact that there is a need for an apology: giving a justification, blaming someone else, or attacking the complainer. In accordance with his own definition of apologies discussed earlier in this paper in the section on definitions of apologies,
Owen classified apologies by the type of utterance they incorporate. Thus, he identified three types of apologies: one that incorporates apology, apologies, or apologize; one that incorporates "sorry;" and finally, the one that is created by the phrase "I'm afraid" followed by a sentence. Owen incorporated apologies in the broader context of primary remedial moves. Thus, there are seven strategies for primary remedial moves: assert imbalance or show deference, assert that an offence has occurred, express attitude towards offence, request restoration of balance, give an account, repair the damage, and provide compensation. The first four are grouped under non-substantive strategies, giving an account is considered a semi-substantive strategy, while the last two are substantive strategies.

Blum-Kulka's apology strategies (1989)

The category named "Intensifies of the apology" consists of six sub-categories:

Intensifying adverbials

Emotional expressions

Expressions marked for register

Double intensifier

Please

Concern for the hearer.

The category named "Taking on responsibility" also consists of six sub-categories:

Explicit self-blame

Lack of intent

Justify hearer

Expression of embarrassment

Admission of facts but not responsibility

Refusal to acknowledge guilt.

The third category named as «Explanation or account» covers any external mitigating circumstances offered by the speaker. The fourth category is «Offer of repair» and the last one is «Promise of forbearance».

AJ Meier's apology strategies (1985)

Speaker-hearer.

Emotives, expressing empathy, expressing negative feeling, explicit acceptance of blame, explicit statement of bad performance, redness, statement of act, thanking.

Hearer-speaker.

This category consists of excuses, justifications, statement of inconsistency, joking.

Speaker $=$ hearer

Routine formula, expressing hope for continuation of status quo, expressing hope for return to status quo.

As a conclusion, it is necessary to say that there are many different categorizations of apologies. However, as already mentioned in the section on 
definitions of Apologies, this speech act is culture specific, so not all the categories in these taxonomies would work for all the cultures. Thus, when creating the taxonomy for a study one should choose those categories that are used in the respective culture. Also, one should account both for explicit and implicit 24 apologies. Finally, categories such as avoiding and postponing apologies should also be part of the taxonomy, as choosing not to apologize or apologize later is also a strategy used when an apology is required.

Data collection information.

Before the role plays were acted out, background questionnaires were administered to all the participants to determine their eligibility for participation in the study. The following paragraphs provide a detailed description of the data elicitation instrument and how it was designed, and in addition to how results from the pilot study helped in refining it. The present study also used enhanced open role plays for data collection. The role plays in the present study consist of twelve situations and include different types of stimuli to apology. These situations also vary with regard to the setting, the status of the interlocutors relative to each other, as well as the object of the apology. These role plays were piloted in the winter 2016, and were found to be effective in eliciting the data.

The role plays in the present study were created based on previous research because similar scenarios have been used in several previous refusal studies investigating learners of English, Spanish, Japanese, Korean, and German. The researcher modified these situations and changed them in some ways, as will be explained below, in order to meet the needs and the context of the present study. The researcher also created a number of new scenarios. These scenarios will be explained below. It is important to indicate here that previous research studies that elicited apology using open role plays followed the guidelines for designing role plays proposed by Hudson, Detmer, and Brown, and these are the following:

- person in addition to the researcher should avoid the overlap of researcher and role play roles;

- a situation should not place too much burden in terms of conceptualization and actualization;

- action should be kept to a minimum and should not involve drama to a large extent;

- action scenarios at the expense of scenarios should be avoided;

- props may be helpful.

The table below shows the 12 role play situations that are used in the present study, and how they vary by refusal stimulus, status of interlocutors relative to each other, object of apology, and setting. This table is followed by a detailed description of each apology situation and how it was designed.

Role plays scenarios.

\begin{tabular}{|l|c|c|c|c|}
\hline Role play & Setting & Social distance & Object of apology & Status \\
\hline Role play №1 & Restaurant & - & Order mistake & $\mathrm{X}<\mathrm{Y}$ \\
\hline Role play №2 & University campus & + & Spoiled book & $\mathrm{X}=\mathrm{Y}$ \\
\hline Role play №3 & University & + & Being late & $\mathrm{X}<\mathrm{Y}$ \\
\hline Role play №4 & Working place & + & E-mail & $\mathrm{X}=\mathrm{Y}$ \\
\hline Role play №5 & Teacher’s room & + & Glance off someone leg & $\mathrm{X}>\mathrm{Y}$ \\
\hline Role play №6 & Bus & - & Being late & $\mathrm{X}>\mathrm{Y}$ \\
\hline Role play №7 & Company meeting & + & Wrong address & $\mathrm{X}<\mathrm{Y}$ \\
\hline Role play №8 & Home entrance & - & Not reported on time & $\mathrm{X}<\mathrm{Y}$ \\
\hline Role play №9 & Work place & + & Broken mobile phone & $\mathrm{X}=\mathrm{Y}$ \\
\hline Role play №10 & Escalator & - & Reserved seat & $\mathrm{X}>\mathrm{Y}$ \\
\hline Role play №11 & Cinema & - & Money & $\mathrm{X}>\mathrm{Y}$ \\
\hline Role play №12 & Money exchange & - & & \\
\hline
\end{tabular}


We used some mathematical formulas to create our role play scenarios. There were some important facts for our research: status of speaker and hearer, do they know each other or not, status of speaker and hearer. So the speaker will be named as "X", the hearer will be "Y", if the status of speaker and hearer equal it will be written as " $\mathrm{X}=\mathrm{Y}$ ", if they are not equal it will be like " $\mathrm{X}>\mathrm{Y}$ " or " $\mathrm{X}<\mathrm{Y}$ ". And if speaker and hearer know each other it will be written like "+", if not "-". So, we would like to summarize the role plays scenarios mentioned above. The instructions for the role plays as well as the twelve role play scenarios were translated on Japanese language. The translation was revised by another native speaker of Japanese who is also fluent in English.

\section{Role Play №1 $\mathrm{X}<\mathrm{Y}(一)$}

あなたはウェイタ一です、お客さんはギリ シャサラダを注文しました。しかしあなたは 注文を間違って、ギシャサラダのかわりにチ キンサラダを持って来ました。お客様に何と 言いますか?

Role Play №2 X=Y $(+)$

あなたは友達から本を借りましたが、お茶 をこぼして、本をよごしてしまいました。友 達に何と言いますか?

Role Play №3 $\mathrm{X}<\mathrm{Y}(+)$

あなたは大学生です。あなたは授業に 20 分ほど遅れました。先生に何と言いますか? 遅れた理由も自分で考えてください。

Role Play №4 X=Y $(+)$

あなたは会社員です。昨日同僚から Ex一 イルがありましたが、仕事が多すぎて、返事 を書くのを忘机てしまいました。同僚に何と 言いますか?

Role Play №5 X>Y (+)

あなたは学部長です。あなたは風邪をひい て、明日の授業にどうしても行けそうにあり ません。A教師に電話をかけて自分の代わりに 代行してほしいと思いました。

あなたはの教師に何と言いますか？

Role Play №6 X=Y (一)

バスは人で混んでいます。あなたは二人側 の席に座っています。あなたは急いで出よう
としたところ、自分のかばんが通路側の人の 頭にあたってしまいました。あなたはその人 に何と言いますか?

Role Play №7 X>Y (+)

あなたは課長です。朝 10 時に部下Aさん と話し合う予定でしたが、突然部長があなた を呼び出して、その部下との話し合いの時刻 に遅れてしまいました。あなたはその部下に 何と言いますか?

Role Play №8 X $<$ Y $(-)$

あなたは郵便局の配達人です。あなたは住 所を間違えて、荷物を届けてしまいました。 間違って荷物を届けた人に何と言いますか?

Role Play №9 $\mathrm{X}<\mathrm{Y}(+)$

あなたは会社員です。あなたは部長にレポ 一トを出さなければいけませんでしたが、時 間に間に合いませんでした。あなたは部長に 何と言いますか?

Role Play №10 X=Y (一)

あなたはエスカレーターを使っています。 突然エスカレーターが止まってしまい、あな たは自分の目の前の人にぶつかってしまいま した。それで、その目の前の人は持っていた 携帯電話を落としてしまいました。携帯の画 面はひびが入ってしまいました。あなたはそ の人に何と言いますか?

Role Play №11 X>Y (一)

あなたは 30 歳の教師です。あなたは映画 館に来ましたが、自分の席を間違えて、2 0 歳くらいの女の子の席に座ってしまいま した。その女の子にあなたは何と言います か?

Role Play №12 X>Y (一)

あなたは銀行でドルを円に両替したいで す。あなたは、記入用紙には 3000 ドルと書 きましたが、銀行員は 290 ドルしかありま せんと言ってきた。銀行の人に何と言います か?

Role plays' results and future plans.

As a result of our survey study we had a role play interview with 10 respondents (Russian speaking students) and now we are going to have an interview with 10 Japan respondents. As a result of role play we plan to compare our results and publish them to public.

\section{References}

1 Gibney M. Rhoda, E.Hassmann H. The age of Apology. - University of Pennsylvania Press. - 2011. - 315 p.

2 Naomi S. "Sorry we apologize so much»: Linguistic Factors Affecting Japanese and U.S. American Styles of Apology. Intercultural Communication Studies VIII. -1998. - P.9

3 Trosborg A. Interlanguage Pragmatics. Requests, Complains and Apologies. -Studies in Anthropological Linguistics. 1995. $-410 \mathrm{p}$. 
4 Brown P., Levinson S.C. Some universals in language usage. - Cambridge University press. - 2004. - 301 p.

5 Fraser B., Turner K. "Language in life and a Life in Language". - BRILL. -2009. - 629 p.

6 Kimura K. "The multiple functions of sumimasen". - Issues in Applied Linguistics. - 2010. - 104 p.

7 Kumatoridani T. Alternation and co-occurrence in Japanese thanks. - Journal of Pragmatics. - 1999. -P. 623-642

8 Gusztav D. A pragmatic study of apology strategies in Romanian. - 2000. - $153 \mathrm{p}$.

9 Mehmet A. Cross Cultural Pragmatics: A Study of Apology Speech Acts by Turkish speakers, American English Speakers and Advance Nonnative Speakers of English in Turkey. - 2013. - 59 p.

10 Elham A. A Cross-Cultural Comparative Study of Apology. - Advances in Language and Literary Studies. - 2016. - 10 p.

11 Ivy Man S.K. The use of apology strategies in public apologies: a comparison between Chinese and English. -2014 . - 118 p.

12 Dubovik A.S. The Problem of Identifying the Semantic Situation of Apology. - Journal of Siberian Federal University. Humanities \& Social Sciences. - 2016. -9 p. 